
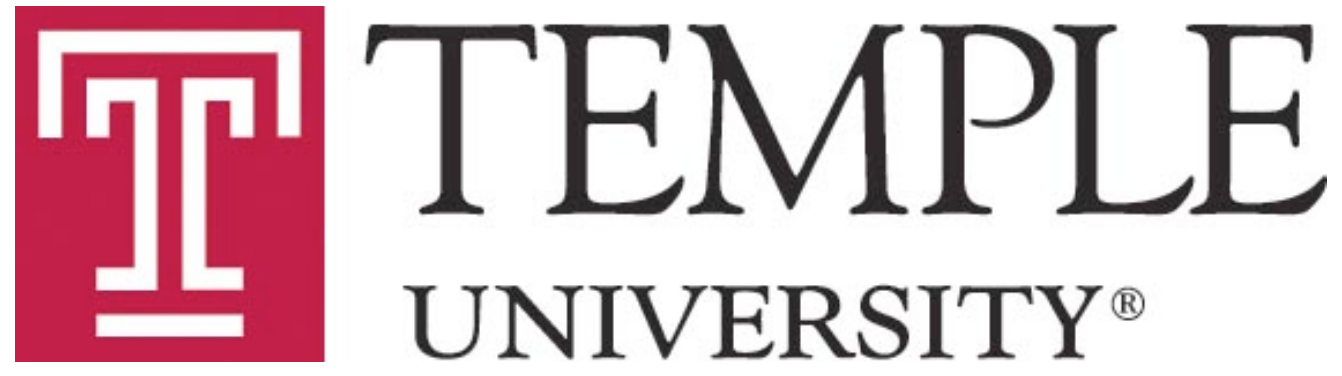

\title{
Unemployment and the Retirement Decisions of Older Workers
}

by

Paul Marmora and Moritz Ritter

Department of Economics

DETU Working Paper 14-01

January 2014

1301 Cecil B. Moore Avenue, Philadelphia, PA 19122

http://www.cla.temple.edu/economics/faculty/detu-working-paper-series/ 


\title{
Unemployment and the Retirement Decisions of Older Workers
}

\author{
Paul Marmora* $\quad$ Moritz Ritter ${ }^{\dagger}$
}

January 2014

\begin{abstract}
This paper examines how unemployment late in workers' careers affects the timing of their retirement. Using data from the Survey of Income and Program Participation from 1996 to 2011, we document that unemployed workers permanently leave the labor force at a significantly higher rate than employed workers. This effect is stronger once workers become eligible for social security benefits and it is significantly dampened by the eligibility for unemployment insurance benefits. Unemployed workers, particularly those workers in households with below median wealth, also have a significantly higher social security uptake rate shortly after turning 62 than employed workers. We find little evidence for housing or stock market effects on the timing of retirement.
\end{abstract}

Keywords: Older Workers, Retirement, Social Security, Unemployment JEL classification: H55, J14, J26, J64, J65

\footnotetext{
${ }^{*}$ Department of Economics, Temple University; e-mail: tuc34842@temple.edu.

${ }^{\dagger}$ Corresponding author. Department of Economics, Temple University; e-mail: moritz.ritter@temple.edu.
} 


\section{Introduction}

At the end of 2013, the U.S. unemployment rate among workers 55 and over was $5.1 \%$. While this is substantially below its peak of $7.4 \%$ in 2010 and below the current national average of $6.7 \%$, it is still substantially above its pre-recession level of $3.1 \%$ in $2007 .^{1}$ Concurrently with the high unemployment rate, the labor force participation rate of workers 55 and older has remained flat at around 40\%, its 2009 level, after increasing steadily from $29.4 \%$ in 1993 . The question of whether the high unemployment and the stagnant labor force participation rates are linked is important when evaluating the state of the labor market. If at least some of those workers out of the labor force are "discouraged" workers, the declining unemployment rate overstates the true state of the labor market (e.g. Fujita, 2013).

While workers of all ages might become "discouraged," older workers are of particular interest in the discussion. First, unemployment spells of older workers are longer, which increases the chance for discouragement. ${ }^{2}$ Second, after turning 62 , older workers typically become eligible for social security benefits, which enables some of them to leave the labor force. However, claiming social security early (i.e. before the full retirement age) causes a permanent reduction in their social security benefits and hence may have a significant effect on the individual worker's welfare.

In this paper, we document that job loss and the subsequent unemployment spell have a large effect on the timing of permanent labor force exit ("retirement") and social security uptake for older workers. We provide evidence that suggests that this effect indeed could be driven by unemployed workers' need for income replacement. In addition, we find that, once we account for employment status, stock and housing market fluctuations have no significant effect on the retirement decision. These findings indicate that the recent slow-down in the labor force participation rate of older workers is likely to be at least partially attributable to the high unemployment in the aftermath of the Great Recession.

Our analysis expands upon recent work by Coile and Levine (2011), who first isolated the opposing effects of aggregate labor and asset market shocks on retirement. Based on March CPS

\footnotetext{
${ }^{1}$ All data from BLS based on the Current Population Survey (CPS).

${ }^{2}$ In December 2013, the average and median unemployment duration for workers 55 to 64 years of age was 47.5 and 25.9 weeks, respectively, compared to an overall average and median of 36.2 and 17.5 weeks, respectively (BLS).
} 
data, their analysis suggests that a high local unemployment rate is more relevant to the retirement decision than asset market shocks, particularly for less-educated workers. In this paper, we use individual-level panel data from the Survey of Income and Program Participation (SIPP), which provides information on the exact timing of labor market transitions, as well as detailed information on income sources, such as social security and unemployment insurance. This detailed labor market data enables us to focus on the individual's labor market status at the time of retirement, rather than having to rely on the local unemployment rate. We find that unemployed workers are significantly more likely to exit the labor force permanently and that this effect is particularly strong for workers eligible for early social security benefits and for workers with few financial assets. These findings are consistent with the hypothesis that older unemployed workers might retire early to draw on social security as an income substitute (income hypothesis).

To further investigate this hypothesis, we utilize information on social security uptake and find that unemployment on one's 62nd birthday increases the probability of social security uptake by 53.4 percentage points for individuals with below median household wealth, but only by 9.8 percentage points for individuals with above median household wealth. Further, consistent with the income hypothesis, we find a spike in retirement after workers' unemployment insurance benefits expire with the spike significantly larger for workers eligible for early social security benefits. Taken together, these findings suggest that recessions could have a significant long-term impact on older workers, as workers who are forced to claim social security benefits early to make ends meet in the short-term will experience a permanent reduction in benefits in the long-term.

Our paper contributes to a growing literature examining the role of the labor market in shaping retirement behavior. It is closest to work by Coile and Levine $(2007,2011)$ who focus on the role of the local unemployment rate in retirement transitions. They find the effect to be significant, but only after workers become eligible for social security, suggesting that workers might claim social security benefits early during economic downturns in an effort to mitigate income losses. Chan and Stevens (1999) estimate that the employment rate of older displaced workers two years after a job loss is 25 percentage points lower than that of similar non-displaced workers, which Chan and Stevens (2004) argue can be partly explained by a reduction in the option value of delaying 
retirement.

In addition to the literature focused on the labor market effect on retirement, we contribute to the literature examining how asset market fluctuations affect retirement rates. The asset data available in the SIPP allow us to study the effect of stock market fluctuations, while simultaneously accounting for employment status - a point stressed by Benitez et al. (2012). Without controlling for employment status, we find that workers in the highest quartile of the wealth distribution respond to stock market fluctuations if they are eligible for social security. However, after controlling for employment status, neither stock nor housing markets have a significant effect on retirement. This is consistent with work by Coile and Levine (2011), who find a small effect of stock market fluctuations on retirement for highly-educated workers, as well as Coile and Levine (2006) and Hurd, et al. (2009), who find no evidence that the stock market boom and bust drove fluctuations in the retirement rate. ${ }^{3}$

\section{Data}

We use data from the 1996, 2001, 2004, and 2008 panels of the Survey of Income and Program Participation (SIPP). Each SIPP panel follows the same individuals over a period ranging from 48 months in the 1996 panel to 32 months in the 2008 panel. For each individual, the SIPP provides employment status at a weekly frequency and income at a monthly frequency, as well as information on total household wealth, typically at an annual frequency. ${ }^{4}$ The relatively high frequency of labor force information allows us to determine whether the retirement decision was preceded by an unemployment spell, and if so, how long that unemployment spell lasted. In addition, the SIPP provides information on all individuals living in the household and their relationship to the household head, which allows us to identify the presence of a working spouse. We restrict our sample to individuals age 55-69 who reported at least one month of labor force participation during the sample period; this results in a sample with 38,998 individuals and 894,687 monthly observations

\footnotetext{
${ }^{3}$ Some evidence suggests that individuals with unexpected capital gains retired earlier during the stock market boom in the late 1990s; see Coronado and Perozek (2003), Sevak (2002), and Cheng and French (2000).

${ }^{4}$ Respondents are interviewed three times per year about their experiences over the previous fourth months. Some "core" information is collected at every interview, while other "topical" information is collected less frequently.
} 
Table 1: Summary statistics by SIPP Panel

\begin{tabular}{cccccc}
\hline Panel & Individuals & $\begin{array}{c}\text { Monthly } \\
\text { Observations }\end{array}$ & Retirements & Job Losses & $\begin{array}{c}\text { Retirements } \\
\text { while Unemployed }\end{array}$ \\
\hline 1996 & 8,167 & 211,694 & 1,802 & 463 & 132 \\
2001 & 7,198 & 156,016 & 1,184 & 437 & 128 \\
2004 & 11,581 & 273,630 & 1,717 & 815 & 310 \\
2008 & 12,052 & 253,347 & 1,518 & 1,006 & 295 \\
\hline
\end{tabular}

for which an individual was in the labor force during the previous month.

In addition to the SIPP data, we employ state-level unemployment data, S\&P stock returns and quarterly state level home values from the Lincoln Institute of Land Policy. The Lincoln Institute of Land Policy calculates the average value of owner-occupied housing in each state by matching property-level data from the Decennial Census of Housing (DCH) with quarterly repeat-sales price indices from the Federal Housing Finance Agency (FHFA). ${ }^{5}$

\section{$2.1 \quad$ Retirement and Unemployment}

For the purpose of our analysis, we require that two conditions be met in order to classify an individual as "retired." First, similarly to Coile and Levine (2011), we define retirement as complete labor force withdrawal: a person exits the labor force for the rest of the survey in month $t$ after participating in the labor force in prior month $t-1$. Second, to account for temporary labor force exits for which we do not observe the end of the spell, we require an individual to self-report that they are either out of the labor force because they are retired, or that they have retired from a job at least once during their lifetime. Using this definition of retirement, we find that the average monthly retirement rate for workers aged 55 to 69 from 1996 to 2011 is $0.68 \%$ ( $7.9 \%$ annually), which is only slightly below the $9 \%$ annual retirement rate in the March CPS from 1980 to 2007 reported in Coile and Levine (2011).

We consider an individual to be "unemployed" if they are without a job and report their labor market status as "no job/business-looking for work" and we define a "job loss" as a separation into unemployment. In other words if a worker is holding a job in $t$ and reports being unemployed in

\footnotetext{
${ }^{5}$ See Davis and Heathcote (2007) for further details.
} 


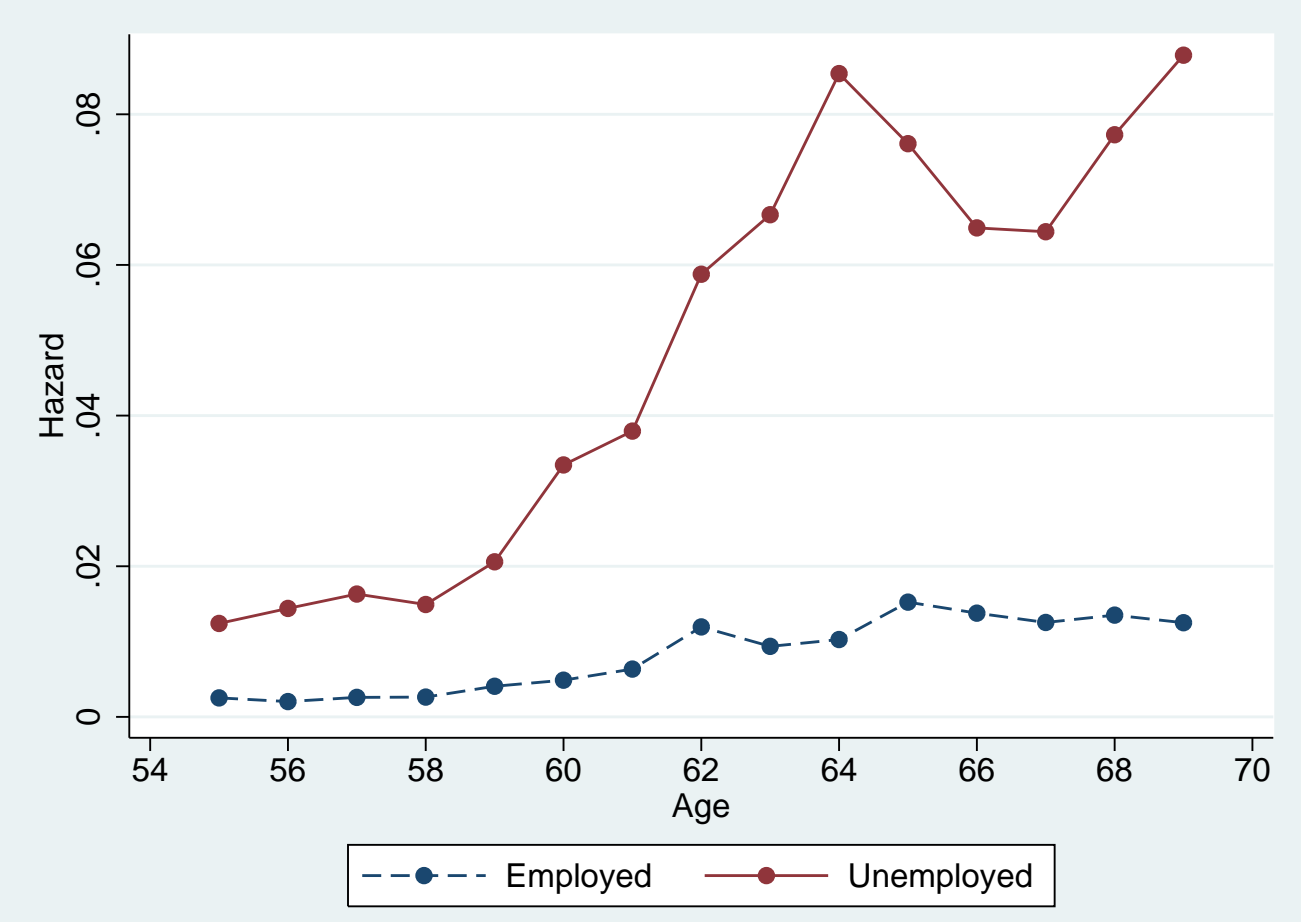

Figure 1: Average Monthly Retirement Rate by Labor Force Status

$t+1$, we consider her as having lost her job. Table 1 lists the number of observations and instances of retirement, job loss and retirement while unemployed for each panel of the SIPP and Figure 1 shows the difference in monthly retirement hazards between the employed and the unemployed, by age. Predictably, the monthly retirement rate for unemployed respondents $(3.2 \%)$ is much higher than the monthly retirement rate for the employed (0.61\%). Unemployed workers also experience much larger spikes in retirement around the eligibility ages for pension and social security benefits: the monthly retirement rate for unemployed individuals age 62 and older is $7.0 \%$, whereas the same rate for employed individuals is only $1.2 \%$, which suggests that unemployed workers might draw on social security and their retirement savings as alternative sources of income.

\subsection{Retirement and Total Household Wealth}

SIPP respondents are asked detailed questions on wealth in the Assets and Liabilities topical module questionnaire, typically administered once a year. We focus on the measure of total net worth at the household level, as retirement behavior is expected to be dependent between spouses (Gustman 
Table 2: Employment and Retirement by Total Household Wealth

\begin{tabular}{lccccc}
\hline & Full Sample & 1st Quartile & 2nd Quartile & 3rd Quartile & 4th Quartile \\
\hline Monthly Retirement Rate & 0.0068 & 0.0062 & 0.0068 & 0.0070 & 0.0069 \\
Unemployment Rate & 0.029 & 0.053 & 0.034 & 0.023 & 0.016 \\
Monthly Job Loss Rate & 0.0029 & 0.0053 & 0.0033 & 0.0025 & 0.0018 \\
$\quad$ into Unemployment & 0.443 & 0.243 & 0.373 & 0.477 & 0.575 \\
Fraction Working Spouse & 38,998 & 9,292 & 12,842 & 14,759 & 14,278 \\
\hline Number of Individuals & 894,687 & 161,178 & 211,739 & 246,235 & 275,535 \\
Number of Monthly Observations & & & & &
\end{tabular}

and Steinmeier, 2004). We assign individuals to quartiles based on total net worth each time the questionnaire is administered. ${ }^{6}$ The individual remains in the wealth quartile until the Assets module is administered the next time. ${ }^{7}$

Table 2 lists the retirement, job loss and unemployment rates for each wealth quartile. Not controlling for age and labor market status, individuals in the lowest wealth quartile retire only at a slightly lower rate ( $7.2 \%$ annually) than individuals in the other three quartiles (7.9-8.1\% annually). On the other hand, the risk of job loss into unemployment decreases strongly with wealth, from $0.5 \%$ monthly separation rate for the lowest wealth quartile, to $0.2 \%$ for the highest quartile. Low wealth households are also much more likely to be single earner households; only $24.3 \%$ of all working individuals in the lowest quartile have a working spouse, compared to $57.5 \%$ for the highest wealth quartile.

Figure 2 shows the age profile of retirement rates for those below and those above the median total household wealth, by age. Higher-asset individuals retire at a slightly higher rate at younger ages, but the trend switches exactly at age 62 and spikes in retirement at age 62 and 65 are considerably more pronounced for those below the median wealth. ${ }^{8}$ Since 62 and 65/66 are the early and full retirement ages, respectively, this pattern is consistent with individuals who have few financial assets making their retirement decision based on social security availability. ${ }^{9}$ On the

\footnotetext{
${ }^{6}$ The primary reason for grouping into quartiles based on net worth instead of using the raw measure of wealth is that total net worth in the SIPP supplemental questionnaire is underreported, particularly for wealthy households (Czajka, et al. 2003).

${ }^{7}$ The first recorded response was used for individuals who appear in the survey before the first Assets and Liabilities topical module release. Respondents who never answered the topical module were excluded from the sample.

${ }^{8}$ The difference in retirement at age 62 is statistically significant at the $10 \%$ level.

${ }^{9}$ Full (normal) retirement age increased during the sample from 65 if born in 1937 or earlier to 66 if born between 1943 and 1954 .
} 


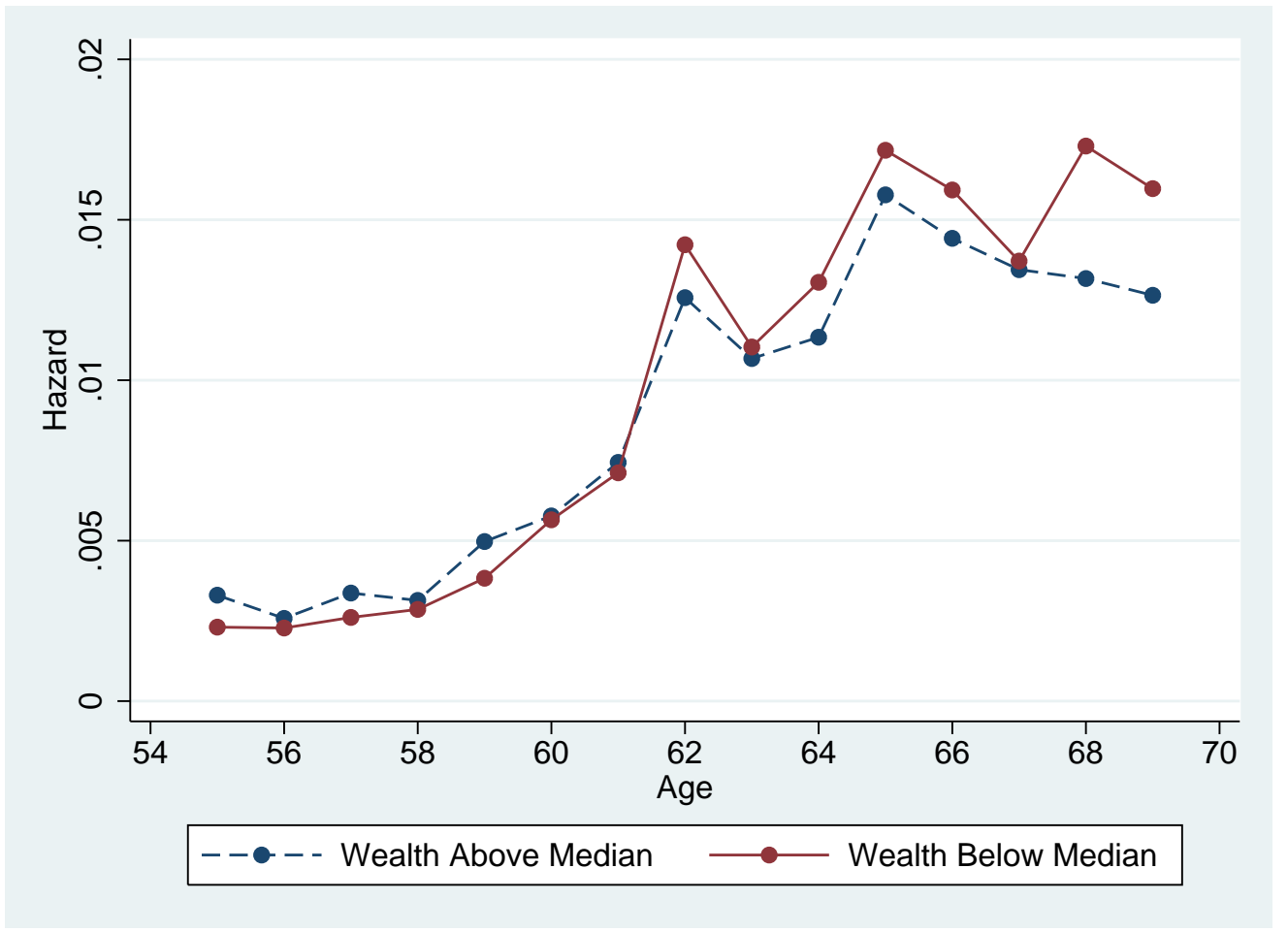

Figure 2: Average Monthly Retirement Rate by Household Wealth

other hand, wealthier workers can afford to make a more independent decision, giving rise to the hypothesis that an unexpected shock to the stock or housing markets may induce high wealth individuals to postpone retirement.

\section{Econometric Analysis of the Retirement Decision}

The previous section showed that both unemployment and wealth affect an individual's retirement decision. In this section, we seek to quantify these effects and explore how the unemployment effect varies with the eligibility for social security benefits, local labor market conditions, and the individual's household wealth. In particular, we follow the approach in Coile and Levine (2011) of using a difference-in-differences linear-probability-model approach to identifying the effects of labor and asset markets on retirement behavior. Exploiting the panel nature of the SIPP, we estimate a fixed effects model, which allows us to control for unobserved heterogeneity that could potentially drive our results (for example, workers who are more likely to be unemployed are also more likely 
to leave the labor force). Thus, our main specification is

$$
\begin{aligned}
\text { Retire }_{i t}= & \beta_{0}+\beta_{1} \text { Unemployed }_{i t}+\beta_{2} \text { UERate }_{i t}+\beta_{3} \text { StockReturn }_{t}+\beta_{4} \text { HomeValue }_{i t} \\
& +\beta_{5} \text { WorkingSpouse }_{i t}+\beta_{6} \text { EarlySSage }_{i t}+\beta_{7} \text { FullSSage }_{i t}+\beta_{8} X_{i t}+\gamma_{i}+\epsilon_{i t}
\end{aligned}
$$

where Retire it $_{\text {is }}$ an indicator variable, equal to one for a worker $i$ being in the labor force in month $t$ but not month $t+1$ or any other future month. The key explanatory variable of interest for a person's retirement decision is her labor market status at the time of retirement, Unemployedit. We include the demeaned state-level unemployment rate (UERate) and indicator variables for the person being of early (EarlySSage) and full social security eligibility age (FullSSage). The asset market effect on retirement is captured by the 5-year S\&P 500 return (StockReturn) and the 5 -year house price return (HomeValue). ${ }^{10}$ Since the retirement decision is expected to be dependent between spouses, we also account for whether an individual has a currently working spouse (WorkingSpouse).

Since we expect individuals' wealth to affect their response to changes in asset prices and potentially also to affect their response to unemployment, we estimate the model separately for each wealth quartile and, in a separate set of regressions, for different education levels. The regressions based on education levels are meant as a robustness check (the more educated, the more likely a person is to own substantial assets) and as a comparison to Coile and Levine (2011).

We allow for interactions between unemployment status, the unemployment rate, early social security eligibility age, and full social security eligibility age to explore the different channels through which labor market conditions might influence retirement. The relationship between labor market status and the retirement decision should become more pronounced when a person reaches eligibility for early social security benefits at age 62 . However, due to the penalty for taking out social security benefits before the normal (full) retirement age, we would expect that unemployed individuals who have sufficient assets to hold them over until full social security age would be less inclined to

\footnotetext{
${ }^{10}$ In addition, we include state and time fixed effects, as well as an indicator variable for the $n$th observation in each panel, which controls for the fact that retirements are more likely to occur later in the panel due to the definition of retirement as exiting the labor force for rest of the survey. We also include an indicator variable for the start of a new wave to address any potential seam-bias problem.
} 
apply for early social security benefits. Therefore, the income hypothesis would be supported if the increase in the retirement rate due to early social security eligibility is stronger for those with fewer assets, those with a lower likelihood of finding a new job, and those who are no longer eligible for unemployment insurance. In addition, during times of high unemployment, job search might be more costly and available jobs less desirable or not available at all, so that the effect of unemployment is stronger during times of tight labor markets.

On the asset side, to capture the potential wealth effect, we include five-year percentage changes in the S\&P 500 and in the value of owner-occupied housing at the state level. Older workers often rely on selling their homes to fund retirement and retirement incomes have also become more susceptible to stock-market fluctuations as defined-contribution accounts are increasingly replacing defined-benefit pensions in both the private and public sectors. Consequently, changes to house prices and stock market returns might affect the timing of retirement, and more so for individuals with substantial assets.

\subsection{Labor Market Results}

\section{Baseline Regressions}

Results of the regression analysis for the full sample, different household wealth and education levels are reported in Tables 3-5. As the results by education are very similar, we focus our discussion on the results by wealth quartiles. The effect of unemployment on retirement is positive and significant across all wealth and education levels. However, the magnitude of this effect differs by wealth level and social security eligibility status. Respondents in the lowest wealth quartile increase their monthly retirement rate by 0.65 percentage points if unemployed before social security eligibility, while the equivalent effect for the highest wealth quartile is 2.0 percentage points; this compares to an average monthly hazard rate for employed individuals age 55 to 61 of $0.3 \%$. The difference between wealth quartiles is not surprising, as job loss should only increase the likelihood of retirement for individuals who either have accumulated enough savings or have an alternative means of retirement income.

Job loss has a stronger effect on retirement for individuals who have reached age 62 , the age of 
early social security benefit eligibility. In the early eligibility group, individuals in the lowest asset quartile experience a relatively larger increase in their retirement rate; their monthly retirement hazard increases by 5.3 percentage point upon becoming unemployed. For individuals in the second and third quartiles, the corresponding increases in hazards are 4.0 and 4.6 percentage points, while unemployed individuals in the fourth asset quartile have a 6.1 percentage points increase in their monthly hazard. This compares to a monthly hazard rate of $1.1 \%$ for employed 62 to 64 year olds. Once individuals reach full social security age, the effect of unemployment on retirement remains positive but is less pronounced than for individuals eligible only for early benefits.

Interestingly, while we find that the unemployment rate has a positive effect on retirement hazards for all workers who are eligible for social security, this effect is very small and mostly loses significance once we separate the sample by wealth. More importantly, the effect of the unemployment rate does not seem to depend on the labor force status of the individual. In other words, the effect of unemployment on retirement does not increase during times of tight labor markets. The only group for which the effect of unemployment is significantly larger during tighter labor markets is individuals with college education eligible for early social security. For this group, a $1 \%$ increase in the unemployment rate above its average increases the monthly retirement rate by 0.56 percentage points, compared to an increase in the retirement rate of 3.5 percentage points caused by being unemployed alone. ${ }^{11}$

One possible explanation could be that some individuals who lose their job transition straight out of the labor force rather than looking for a job. If such behavior is more common during times of high unemployment, that would be consistent with the countercyclical retirement rate for individuals eligible for early social security benefits. In addition, during times of high unemployment, the duration of eligibility for unemployment insurance benefits is extended, lessening the potential need for unemployed individuals to draw on social security as an income source. We will discuss this possibility in more detail below.

\section{Income Hypothesis and Social Security Eligibility}

One possible explanation for the increase in the retirement rate for unemployed workers is that

\footnotetext{
${ }^{11}$ We explored the possibility that the labor market effect is asymmetric and unemployment only affects the retirement behavior during times of high unemployment. This did not change results significantly.
} 
they have to rely on social security benefits because they cannot find a new job before running out of unemployment benefits (income hypothesis). This explanation is consistent with the strong increase in retirement after reaching eligibility for social security benefits, in particular for individuals in the lowest quartile of the wealth distribution. In addition to household assets, we would expect that the unemployment of one family member should matter less for retirement in households with more than one income than in single earner households. We do, indeed, find that the presence of a working spouse lowers the retirement rate for unemployed individuals, though not statistically significantly so.

More importantly, according to the income hypothesis, we would expect a strong effect of unemployment on retirement at the time a worker becomes eligible for social security benefits at age 62 . We focus therefore on the first 6 months after an individual turns 62 and estimate the effect of unemployment in the month of a worker's 62 nd birthday on the probability of retirement within 6 months of her 62 nd birthday. Overall, about $9.2 \%$ of all workers in our sample who are in the labor force on their 62nd birthday leave the labor force within 6 months. As shown in Table 6, being unemployed on one's 62nd birthday has a large and significant effect on the 6 month retirement probability: for individuals with below median wealth, all else equal, being unemployed increases the probability of a retirement shortly after becoming eligible for social security benefits by 23.4 percentage points. For individuals with above median assets, the effect is 12.8 percentage points, but not statistically significant.

Our definition of retirement above focuses on labor force exit, rather than social security uptake. The main reason for this is the lapse of time between the application for social security benefits and the beginning of payouts, which complicates the identification of the exact timing of the retirement decision. However, if retirements by the unemployed are truly driven by the need for an income, as suggested above, we should see a large effect of unemployment on social security uptake. We can again use the discontinuity in eligibility at age 62 to study the effect of unemployment on uptake of social security benefits. Following the same approach as above, we estimate the effect of being unemployed on the 62 nd birthday on social security uptake within 6 months of turning $62 .{ }^{12}$

\footnotetext{
${ }^{12}$ We require individuals to start reporting income from social security within 6 months of the 62 nd birthday. Due to the aforementioned processing time, this requires an application for social security benefits within 2-3 months of
} 
Overall, in our sample of workers in the labor force, $29.7 \%$ of workers with below median household wealth and $24.3 \%$ of workers with above median wealth take up social security within 6 months of turning 62 .

The results are reported in Table 7 and are strongly supportive of the income hypothesis: for individuals with below median assets, being unemployed on the 62 nd birthday increases the probability of taking up social security by 53.3 percentage points, compared to only 9.8 percentage points for an individual with above median wealth. Since the average take-up rate for below median wealth individuals in our sample is $29.7 \%$, this suggests that the large majority of unemployed workers with below median wealth take up social security early. Also, consistent with the income hypothesis, we do not find the same effect for above median wealth individuals. The presence of a working spouse lowers the uptake probability, independent of the wealth level. Moreover, the presence of a working spouse also greatly dampens the effect of unemployment on the retirement of low wealth individuals, although not significantly so.

\section{Unemployment Duration}

Lastly, returning to our original definition of retirement, we study the effect of unemployment duration on retirement. Under the income hypothesis, the timing of retirement (and social security withdrawal) should be affected by the availability of unemployment insurance (UI): permanent labor force exit should increase around the time of the expiration of any unemployment insurance benefits. To study the effect of the expiration of UI benefits, we first classify all unemployment spells in our sample into two groups: spells for which the unemployed individual received benefits at least once and those spells for which no benefits where ever reported. ${ }^{13}$ Next, we break up each unemployment spell into three sub-spells: the initial period after job loss, with potential UI coverage (typically 26 weeks, but may be longer during times of extended benefits due to a weak labor market); the 26 weeks after the expiration date ("after" period) and more than 26 weeks after the expiration date ("long term" period). Thus, at any point during an unemployment spell,

turing 62 , at the latest.

${ }^{13}$ Unemployment insurance benefits appear to be slightly underreported in the SIPP, as only $48.2 \%$ of the unemployed in our sample report having received UI benefits during an unemployment spell. To the effect that underreporting leads to a downward bias for the effect of expiration of UI benefits, our results might be viewed as a lower bound. 
an individual can be in one of six potential groups, determined by UI eligibility and time since job loss (the three sub-spell periods).

We then estimate a variation of the model in the previous section, but including indicator variables for an unemployed individual being in each of the six groups, while allowing the effect to vary with social security eligibility. Results are reported in Table 8. For all age groups, workers not receiving UI benefits have a significantly larger retirement probability during the UI coverage period than observationally equivalent employed workers. As before, the effect of unemployment is significantly larger once workers reach social security eligibility age: before age 62 , being unemployed and not receiving UI benefits increases a worker's monthly retirement rate by 1.6 percentage points; after turning 62, the equivalent effect is 7.0 percentage points. Receiving UI benefits significantly dampens the effect of unemployment: before age 62, the retirement rate of unemployed workers receiving UI benefits is statistically indistinguishable from the retirement rate for employed workers. After age 62, the effect of unemployment falls to 2.8 percentage points with the receipt of UI benefits.

After the eligibility for UI benefits runs out, but before age 62 , workers previously receiving benefits behave similarly to those never receiving benefits. However, after age 62, workers who lost their UI benefits experience a large spike in retirement, consistent with the income hypothesis. Workers eligible for early social security and who ran out of UI benefits retire at a rate 11.3 percentage points higher than those never eligible for UI benefits and 13.5 percentage points higher than employed workers eligible for early social security benefits.

As mentioned above, one possible explanation for the unresponsiveness of the retirement decision to changes in the unemployment rate is that the only period with severely elevated unemployment in our sample coincides with a substantial extension in the duration of unemployment benefits. Starting in July 2008, eligibility for unemployment benefits was extended beyond 26 weeks and, by November 2009, the maximum duration reached 99 weeks. If retirement is driven by the income gap once eligibility for UI benefits expires, we would expect to find a strong effect during the "after" period during times of regular benefit duration but not during the long extension of 99 weeks when the regular "after" period is still covered by UI. I.e. if retirement is driven by income 
replacement rather than a simple discouragement effect, we expect a covered worker would respond differently in week 27 of his unemployment spell if the coverage period is 26 weeks than if it is 99 weeks.

To explore whether workers' retirement is driven by discouragement rather than income replacement, we focus on time periods with "regular" UI benefits (26 weeks) and the time period with the longest extension of benefits in our sample (99 weeks) and estimate similar specifications as above. For all unemployment spells, we set the "after" period to be the regular "after" period (regardless of whether benefits are extended or not). In the specifications, we include interactions with an indicator for the 99 week extensions. As shown in Table 9, we find that covered workers retire at a lower rate during periods with regular benefits. Since the sample is pooled by age, however, we no longer observe a large spike around expiration of benefits as we do for the covered group eligible for early social security benefits in Table 8 .

The bottom half of Table 9 shows the differential retirement rates during periods of extended benefits. Consistent with the income hypothesis, workers receiving UI benefits retire at significantly lower rates during "after" periods with extended benefits than do covered workers who are no longer eligible for UI benefits in "after" periods following periods with regular benefits. In the first 26 weeks of the UI extension, the monthly retirement rate is 2.7 percentage points lower than the rate for comparable workers who run out of benefits during regular benefit periods and 5.6 percentage points smaller after 52 weeks of unemployment. On the other hand, workers not receiving UI benefits do not exhibit different retirement behavior than workers not covered during regular benefit periods.

\subsection{Stock Returns and Housing Market Results}

Tables 3-5 also explore the retirement response to changes in annual S\&P 500 returns and state land values. The effects of these two factors are not significant for any wealth/education groups, suggesting that the wealth effect from changes in stock and house values might not play a significant role in agents' retirement decisions. However, it is possible that the wealth effect differs by age and a specification using the entire sample is hindering identification (e.g. defined-contribution pension plans are often unavailable before age 59). In addition, Coile and Levine (2011) find that 
long-run stock returns affect the retirement of educated workers only after age 62 . To explore this possibility, we similarly divide the sample by age. As Table 11 shows, restricting the sample to individuals age 62 and older and excluding labor market controls does lead to a significant positive effect of annual S\&P 500 returns on retirement for individuals in the highest wealth quartile. For individuals ages $62-69$, the estimated effect of a $25 \%$ increase in five-year returns is a $1 \%$ increase

in the retirement rate for individuals in the fourth quartile of the wealth distribution. However, as we reintroduce some of the additional labor market covariates and the spouse's employment status, the stock market effect ceases to be significant.

Similarly to Coile and Levine (2011), we find that changes in land value, our proxy for house prices, do not affect retirement decisions. While this channel has received a lot of attention in the popular press, our finding is consistent with other research suggesting that home equity plays a minor role in the financing of consumption during retirement.

\section{Conclusion}

Contrary to the popular story line at the onset of the Great Recession, stock market booms or busts have a significantly smaller effect on the retirement decision than unemployment does late in a worker's career. We hypothesize that this could be driven by the need to find an alternative income source given the low job finding rate for older workers (income hypothesis) and provide strong evidence in favor of that hypothesis. These findings have potentially important implications for the evaluation of the state of the labor market, especially in light of the expiration of the Emergency Unemployment Compensation at the end of 2013.

Our work is consistent with recent reports in the press and anecdotal evidence (e.g. Goyer, 2013, finds in a survey of 1003 boomers born in 1946 that 10\% of those retired list "laid off and couldn`t find work" as reason for retirement). Since retiring early leads to a permanent reduction in social security benefits an individual will receive for the rest of her life, this suggests that unemployment late in a worker's career can have a significant effect on that worker's remaining-life income. Consequently, we believe that this issue warrants further attention in future research. 


\section{References}

[1] Benitez-Silva, Hugo, J. Ignacio Garcia-Perez, and Sergi Jimenez-Martin (2012): "The Effects of Employment Uncertainty and Wealth Shocks on the Labor Supply and Claiming Behavior of Older American Workers." No 12-12, Department of Economics Working Papers, Stony Brook University, Department of Economics.

[2] Chan, Sewin and Ann Huff Stevens (1999): "Employment and Retirement Following a LateCareer Job Loss." American Economic Review 89(2), pages 211-216.

[3] Chan, Sewin and Ann Huff Stevens (2004): "How Does Job Loss Affect the Timing of Retirement?" The B.E. Journal of Economic Analysis and Policy, De Gruyter, 3(1), pages 1-26, May.

[4] Cheng, Ing-Haw and Eric French (2000): "The Effect of the Run-Up in the Stock Market on Labor Supply." Economic Perspectives, Federal Reserve Bank of Chicago, 24(4), pages 48-65.

[5] Coile, Courtney C. and Phillip B. Levine (2006): "Bulls, Bears, and Retirement Behavior." Industrial and Labor Relations Review 59(3), pages 408-429, April.

[6] Coile, Courtney C. and Phillip B. Levine (2007): "Labor Market Shocks and Retirement: Do Government Programs Matter?" Journal of Public Economics 91(10), pages1902-1919, November.

[7] Coile, Courtney C. \& Phillip B. Levine (2011): "The Market Crash and Mass Layoffs: How the Current Economic Crisis May Affect Retirement." The B.E. Journal of Economic Analysis 6 Policy, De Gruyter, 11(1), pages 1-42, April.

[8] Coronado, Julie and Maria Perozek (2003): "Wealth Effects and the Consumption of Leisure: Retirement Decisions During the Stock Market Boom of the 1990s." Board of Governors of the Federal Reserve System Finance and Economics Discussion Series \#2003-20. 
[9] Czajka, John L., Jonathon E. Jacobson and Scott Cody (2003): "Survey Estimates of Wealth: A Comparative Analysis and Review of the Survey of Income and Program Participation." Washington, DC: Mathematica Policy Research, Inc. Document No. PR03-45,330 Pages.

[10] Davis, Morris A. and Jonathan Heathcote (2007): "The Price and Quantity of Residential Land in the United States. "Journal of Monetary Economics, 54(8), pages 2595-2620.

[11] Fujita, Shigeru (2013): "On the Causes of Declines in the Labor Force Participation Rate." Federal Reserve Bank of Philadelphia, Research Rap.

[12] Goyer, Amy (2013): "The MetLife Report on The Oldest Boomers." MetLife Mature Market Institute.

[13] Gustman, Alan L. and Thomas L. Steinmeier (2004): "Social Security, Pensions And Retirement Behavior Within The Family." Journal of Applied Econometrics. 19(6), pages. 723-73.

[14] Hurd, Michael D., Monika Reti, and Susann Rohwedder (2009): "The Effect of Large Capital Gains or Losses on Retirement." in David Wise(ed.),Developments in the Economics of Aging. Chicago: University of Chicago Press.

[15] Sevak, Purvi (2002). "Wealth Shocks and Retirement Timing: Evidence from the Nineties." Working Papers wp027, University of Michigan, Michigan Retirement Research Center. 
Table 3: Retirement Transitions, FE

\begin{tabular}{|c|c|c|c|c|}
\hline & (1) & $(2)$ & $(3)$ & $(4)$ \\
\hline Mean of Dependent Variable & 0.0068 & 0.0068 & 0.0068 & 0.0068 \\
\hline EarlySSage & $\begin{array}{c}0.0065^{* * *} \\
(0.0007)\end{array}$ & $\begin{array}{c}0.0055^{* * *} \\
(0.0007)\end{array}$ & $\begin{array}{c}0.0066^{* * *} \\
(0.0007)\end{array}$ & $\begin{array}{c}0.0055^{* * *} \\
(0.0007)\end{array}$ \\
\hline FullSSage & $\begin{array}{c}0.0116^{* * *} \\
(0.0015)\end{array}$ & $\begin{array}{c}0.0106^{* * *} \\
(0.0014)\end{array}$ & $\begin{array}{c}0.0117^{* * *} \\
(0.0015)\end{array}$ & $\begin{array}{c}0.0106^{* * *} \\
(0.0014)\end{array}$ \\
\hline WorkingSpouse & $\begin{array}{c}-0.0032^{* * *} \\
(0.0006)\end{array}$ & $\begin{array}{c}-0.0033^{* * *} \\
(0.0006)\end{array}$ & & $\begin{array}{c}-0.0033^{* * *} \\
(0.0006)\end{array}$ \\
\hline Unemployed & $\begin{array}{c}0.0209^{* * *} \\
(0.0019)\end{array}$ & $\begin{array}{c}0.0118^{* * *} \\
(0.0017)\end{array}$ & & $\begin{array}{c}0.0118^{* * *} \\
(0.0017)\end{array}$ \\
\hline UERate & $\begin{array}{c}0.0003 \\
(0.0003)\end{array}$ & $\begin{array}{c}0.0000 \\
(0.0003)\end{array}$ & & $\begin{array}{c}0.0001 \\
(0.0003)\end{array}$ \\
\hline Unemployed ${ }^{*}$ WorkingSpouse & $\begin{array}{c}-0.0054^{*} \\
(0.0028)\end{array}$ & $\begin{array}{l}-0.0033 \\
(0.0028)\end{array}$ & & $\begin{array}{l}-0.0033 \\
(0.0028)\end{array}$ \\
\hline Unemployed ${ }^{*} U$ ERate & $\begin{array}{c}0.0005 \\
(0.0006)\end{array}$ & $\begin{array}{l}-0.0002 \\
(0.0005)\end{array}$ & & $\begin{array}{l}-0.0002 \\
(0.0005)\end{array}$ \\
\hline Unemployed $^{*}$ EarlySSage & & $\begin{array}{c}0.0387^{* * *} \\
(0.0057)\end{array}$ & & $\begin{array}{c}0.0387^{* * *} \\
(0.0057)\end{array}$ \\
\hline Unemployed*FullSSage & & $\begin{array}{c}0.0321^{* * *} \\
(0.0081)\end{array}$ & & $\begin{array}{c}0.0321^{* * *} \\
(0.0081)\end{array}$ \\
\hline UERate*EarlySSage & & $\begin{array}{c}0.0008^{* * *} * \\
(0.0002)\end{array}$ & & $\begin{array}{c}0.0008^{* * *} \\
(0.0002)\end{array}$ \\
\hline UERate* FullSSage & & $\begin{array}{l}0.0006^{*} \\
(0.0003)\end{array}$ & & $\begin{array}{c}0.0006^{*} \\
(0.0003)\end{array}$ \\
\hline Unemployed $^{*} U$ ERate* EarlySSage & & $\begin{array}{c}0.0015 \\
(0.0020)\end{array}$ & & $\begin{array}{c}0.0015 \\
(0.0020)\end{array}$ \\
\hline Unemployed ${ }^{*} U$ ERate* FullSSage & & $\begin{array}{c}0.0003 \\
(0.0025)\end{array}$ & & $\begin{array}{c}0.0003 \\
(0.0025)\end{array}$ \\
\hline StockReturn $* 100$ & & & $\begin{array}{c}0.0063 \\
(0.0057)\end{array}$ & $\begin{array}{c}0.0067 \\
(0.0057)\end{array}$ \\
\hline HomeValue ${ }^{*} 100$ & & & $\begin{array}{l}-0.0006 \\
(0.0015)\end{array}$ & $\begin{array}{c}0.0003 \\
(0.0016)\end{array}$ \\
\hline $\begin{array}{l}\text { Number of Observations } \\
\text { Number of Individuals }\end{array}$ & $\begin{array}{c}894687 \\
38998\end{array}$ & $\begin{array}{c}894687 \\
38998\end{array}$ & $\begin{array}{c}894687 \\
38998\end{array}$ & $\begin{array}{c}894687 \\
38998\end{array}$ \\
\hline \multicolumn{5}{|c|}{$\begin{array}{l}\text { s.e. in parentheses } \\
\left({ }^{* *}\right) \text { denotes significance at the } 1 \% \text { level, }\left({ }^{*}\right) \text { at the } 5 \% \text { level, }\left({ }^{*}\right) \text { at the } 10 \% \text { level } \\
\text { Each specification is a fixed effects regression with Retire as the dependent variable. We also include } \\
\text { controls for age, as well as time and state fixed effects, an indicator variable for the beginning of a new } \\
\text { wave, and an indicator variable for the nth observation in each panel. Standard errors are clustered at } \\
\text { the individual level. }\end{array}$} \\
\hline
\end{tabular}


Table 4: Retirement Transitions by Total Household Net Worth, FE

\begin{tabular}{|c|c|c|c|c|}
\hline & 1st Quartile & 2nd Quartile & 3rd Quartile & 4th Quartile \\
\hline Mean of Dependent Variable & 0.0062 & 0.0068 & 0.0071 & 0.0069 \\
\hline EarlySSage & $\begin{array}{c}0.0027 \\
(0.0018)\end{array}$ & $\begin{array}{c}0.0065^{* * *} \\
(0.0017)\end{array}$ & $\begin{array}{c}0.0059^{* * *} \\
(0.0016)\end{array}$ & $\begin{array}{c}0.0048^{* * *} \\
(0.0013)\end{array}$ \\
\hline FullSSage & $\begin{array}{c}0.0073^{* *} \\
(0.0036)\end{array}$ & $\begin{array}{c}0.0102^{* * * *} \\
(0.0034)\end{array}$ & $\begin{array}{c}0.0109^{* * *} \\
(0.0030)\end{array}$ & $\begin{array}{c}0.0094^{* * *} \\
(0.0025)\end{array}$ \\
\hline WorkingSpouse & $\begin{array}{l}-0.0000 \\
(0.0012)\end{array}$ & $\begin{array}{c}-0.0021^{*} \\
(0.0012)\end{array}$ & $\begin{array}{c}-0.0042^{* * *} \\
(0.0013)\end{array}$ & $\begin{array}{c}-0.0042^{* * *} \\
(0.0010)\end{array}$ \\
\hline Unemployed & $\begin{array}{c}0.0065^{* * *} \\
(0.0022)\end{array}$ & $\begin{array}{c}0.0135^{* * *} \\
(0.0033)\end{array}$ & $\begin{array}{c}0.0124^{* * *} \\
(0.0038)\end{array}$ & $\begin{array}{c}0.0200^{* * *} \\
(0.0059)\end{array}$ \\
\hline UERate & $\begin{array}{l}-0.0002 \\
(0.0007)\end{array}$ & $\begin{array}{c}0.0008 \\
(0.0006)\end{array}$ & $\begin{array}{c}0.0000 \\
(0.0006)\end{array}$ & $\begin{array}{l}-0.0003 \\
(0.0005)\end{array}$ \\
\hline Unemployed ${ }^{*}$ WorkingSpouse & $\begin{array}{l}-0.0053 \\
(0.0041)\end{array}$ & $\begin{array}{l}-0.0037 \\
(0.0052)\end{array}$ & $\begin{array}{l}-0.0064 \\
(0.0060)\end{array}$ & $\begin{array}{l}-0.0074 \\
(0.0077)\end{array}$ \\
\hline Unemployed ${ }^{*} U$ ERate & $\begin{array}{c}0.0006 \\
(0.0008)\end{array}$ & $\begin{array}{l}-0.0000 \\
(0.0010)\end{array}$ & $\begin{array}{l}-0.0002 \\
(0.0009)\end{array}$ & $\begin{array}{l}-0.0005 \\
(0.0017)\end{array}$ \\
\hline Unemployed ${ }^{*}$ EarlySSage & $\begin{array}{c}0.0464^{* * *} \\
(0.0120)\end{array}$ & $\begin{array}{c}0.0266^{* * * *} \\
(0.0101)\end{array}$ & $\begin{array}{c}0.0336^{* * *} \\
(0.0113)\end{array}$ & $\begin{array}{c}0.0413^{* * *} \\
(0.0134)\end{array}$ \\
\hline Unemployed*FullSSage & $\begin{array}{c}0.0247 \\
(0.0164)\end{array}$ & $\begin{array}{c}0.0126 \\
(0.0140)\end{array}$ & $\begin{array}{c}0.0423^{* *} \\
(0.0171)\end{array}$ & $\begin{array}{l}0.0332^{*} \\
(0.0179)\end{array}$ \\
\hline UERate*EarlySSage & $\begin{array}{l}0.0010^{*} \\
(0.0006)\end{array}$ & $\begin{array}{c}0.0004 \\
(0.0005)\end{array}$ & $\begin{array}{c}0.0011^{* *} \\
(0.0005)\end{array}$ & $\begin{array}{c}0.0004 \\
(0.0004)\end{array}$ \\
\hline UERate $^{*}$ FullSSage & $\begin{array}{c}0.0009 \\
(0.0009)\end{array}$ & $\begin{array}{l}-0.0001 \\
(0.0008)\end{array}$ & $\begin{array}{c}0.0003 \\
(0.0007)\end{array}$ & $\begin{array}{c}0.0005 \\
(0.0006)\end{array}$ \\
\hline Unemployed ${ }^{*} U$ ERate*EarlySSage & $\begin{array}{l}-0.0010 \\
(0.0038)\end{array}$ & $\begin{array}{c}0.0055 \\
(0.0042)\end{array}$ & $\begin{array}{c}0.0030 \\
(0.0040)\end{array}$ & $\begin{array}{c}0.0027 \\
(0.0045)\end{array}$ \\
\hline Unemployed ${ }^{*} U$ ERate ${ }^{*}$ FullSSage & $\begin{array}{c}0.0034 \\
(0.0050)\end{array}$ & $\begin{array}{l}-0.0014 \\
(0.0035)\end{array}$ & $\begin{array}{c}0.0004 \\
(0.0059)\end{array}$ & $\begin{array}{l}-0.0017 \\
(0.0068)\end{array}$ \\
\hline StockReturn*100 & $\begin{array}{l}-0.0143 \\
(0.0127)\end{array}$ & $\begin{array}{c}0.0145 \\
(0.0130)\end{array}$ & $\begin{array}{c}0.0094 \\
(0.0115)\end{array}$ & $\begin{array}{c}0.0159 \\
(0.0114)\end{array}$ \\
\hline HomeValue *100 & $\begin{array}{l}-0.0011 \\
(0.0042)\end{array}$ & $\begin{array}{c}0.0059 \\
(0.0040)\end{array}$ & $\begin{array}{c}0.0025 \\
(0.0033)\end{array}$ & $\begin{array}{l}-0.0013 \\
(0.0031)\end{array}$ \\
\hline $\begin{array}{l}\text { Number of Observations } \\
\text { Number of Individuals }\end{array}$ & $\begin{array}{c}161178 \\
9292\end{array}$ & $\begin{array}{c}211739 \\
12842\end{array}$ & $\begin{array}{c}246235 \\
14759\end{array}$ & $\begin{array}{c}275535 \\
14278\end{array}$ \\
\hline $\begin{array}{l}\text { s.e. in parentheses } \\
\left({ }^{* *}\right) \text { denotes significance at the } 1 \% \text { level, } \\
\text { Each specification is a fixed effects regressi } \\
\text { controls for age, as well as time and state } \mathrm{f} \\
\text { wave, and an indicator variable for the nth } \\
\text { the individual level. }\end{array}$ & $\begin{array}{l}*) \text { at the } 5 \% \text { lev } \\
\text { on with Retire } \\
\text { xed effects, an ir } \\
\text { observation in e }\end{array}$ & $\begin{array}{l}\text { s }(*) \text { at the } 10 \% \\
\text { the dependent } \\
\text { dicator variable } \mathrm{f} \\
\text { ch panel. Standa }\end{array}$ & $\begin{array}{l}\text { level } \\
\text { ariable. We als } \\
\text { r the beginning } \\
\text { rd errors are clu }\end{array}$ & $\begin{array}{l}\text { aclude } \\
\text { a new } \\
\text { red at }\end{array}$ \\
\hline
\end{tabular}


Table 5: Retirement Transitions by Highest Education Attained, FE

\begin{tabular}{|c|c|c|c|}
\hline & High School or Less & College Degree/Some College & Post-College \\
\hline Mean of Dependent Variable & 0.0081 & 0.0063 & 0.0051 \\
\hline EarlySSage & $\begin{array}{c}0.0081^{* * *} \\
(0.0013)\end{array}$ & $\begin{array}{c}0.0048^{* * *} \\
(0.0011)\end{array}$ & $\begin{array}{c}0.0010 \\
(0.0015)\end{array}$ \\
\hline FullSSage & $\begin{array}{c}0.0149^{* * *} \\
(0.0024)\end{array}$ & $\begin{array}{c}0.0085^{* * *} \\
(0.0022)\end{array}$ & $\begin{array}{c}0.0038 \\
(0.0032)\end{array}$ \\
\hline WorkingSpouse & $\begin{array}{c}-0.0032^{* * *} \\
(0.0009)\end{array}$ & $\begin{array}{c}-0.0036^{* * *} \\
(0.0009)\end{array}$ & $\begin{array}{l}-0.0022 \\
(0.0014)\end{array}$ \\
\hline Unemployed & $\begin{array}{c}0.0111^{* * *} \\
(0.0028)\end{array}$ & $\begin{array}{c}0.0115^{* * *} \\
(0.0023)\end{array}$ & $\begin{array}{c}0.0165^{* *} \\
(0.0076)\end{array}$ \\
\hline UERate & $\begin{array}{c}0.0002 \\
(0.0005)\end{array}$ & $\begin{array}{l}-0.0000 \\
(0.0004)\end{array}$ & $\begin{array}{l}-0.0009 \\
(0.0006)\end{array}$ \\
\hline Unemployed ${ }^{*}$ WorkingSpouse & $\begin{array}{l}-0.0039 \\
(0.0047)\end{array}$ & $\begin{array}{l}-0.0015 \\
(0.0037)\end{array}$ & $\begin{array}{l}-0.0095 \\
(0.0094)\end{array}$ \\
\hline Unemployed ${ }^{*} U$ ERate & $\begin{array}{c}0.0006 \\
(0.0009)\end{array}$ & $\begin{array}{l}-0.0011 \\
(0.0007)\end{array}$ & $\begin{array}{c}0.0004 \\
(0.0023)\end{array}$ \\
\hline Unemployed ${ }^{*}$ EarlySSage & $\begin{array}{c}0.0528^{* * *} \\
(0.0098)\end{array}$ & $\begin{array}{c}0.0234^{* * *} \\
(0.0073)\end{array}$ & $\begin{array}{c}0.0538^{* * *} \\
(0.0180)\end{array}$ \\
\hline Unemployed $^{*}$ FullSSage & $\begin{array}{c}0.0417^{* * *} \\
(0.0135)\end{array}$ & $\begin{array}{c}0.0233^{* *} \\
(0.0098)\end{array}$ & $\begin{array}{c}0.0161 \\
(0.0316)\end{array}$ \\
\hline UERate*EarlySSage & $\begin{array}{c}0.0007 \\
(0.0004)\end{array}$ & $\begin{array}{l}0.0006^{*} \\
(0.0003)\end{array}$ & $\begin{array}{c}0.0015^{* * *} \\
(0.0005)\end{array}$ \\
\hline UERate* FullSSage & $\begin{array}{c}0.0007 \\
(0.0006)\end{array}$ & $\begin{array}{c}0.0004 \\
(0.0005)\end{array}$ & $\begin{array}{c}0.0011 \\
(0.0008)\end{array}$ \\
\hline Unemployed $^{*} U$ ERate* EarlySSage & $\begin{array}{l}-0.0019 \\
(0.0035)\end{array}$ & $\begin{array}{c}0.0056^{* *} \\
(0.0025)\end{array}$ & $\begin{array}{l}-0.0016 \\
(0.0072)\end{array}$ \\
\hline Unemployed ${ }^{*} U$ ERate ${ }^{*}$ FullSSage & $\begin{array}{l}-0.0073^{*} \\
(0.0039)\end{array}$ & $\begin{array}{c}0.0064^{* *} \\
(0.0032)\end{array}$ & $\begin{array}{l}-0.0015 \\
(0.0114)\end{array}$ \\
\hline StockReturn*100 & $\begin{array}{c}0.0024 \\
(0.0094)\end{array}$ & $\begin{array}{c}0.0047 \\
(0.0086)\end{array}$ & $\begin{array}{c}0.0056 \\
(0.0137)\end{array}$ \\
\hline HomeValue*100 & $\begin{array}{c}0.0008 \\
(0.0033)\end{array}$ & $\begin{array}{c}0.0009 \\
(0.0021)\end{array}$ & $\begin{array}{l}-0.0008 \\
(0.0035)\end{array}$ \\
\hline $\begin{array}{l}\text { Number of Observations } \\
\text { Number of Individuals }\end{array}$ & $\begin{array}{c}344747 \\
15518\end{array}$ & $\begin{array}{c}425164 \\
18619\end{array}$ & $\begin{array}{c}124776 \\
5237\end{array}$ \\
\hline
\end{tabular}

s.e. in parentheses

$(* * *)$ denotes significance at the $1 \%$ level, $(* *)$ at the $5 \%$ level, $(*)$ at the $10 \%$ level

Each specification is a fixed effects regression with Retire as the dependent variable. We also include controls for age, as well as time and state fixed effects, an indicator variable for the beginning of a new wave, and an indicator variable for the nth observation in each panel. Standard errors are clustered at the individual level. 
Table 6: Retirement at 62nd Birthday

\begin{tabular}{|c|c|c|c|}
\hline & Full Sample & Below Median & Above Median \\
\hline Mean of Dependent Variable & 0.0923 & 0.0969 & 0.0893 \\
\hline WorkingSpouse & $\begin{array}{c}-0.0311^{* * *} \\
(0.0093)\end{array}$ & $\begin{array}{l}-0.0196 \\
(0.0168)\end{array}$ & $\begin{array}{c}-0.0406^{* * *} \\
(0.0127)\end{array}$ \\
\hline Unemployed & $\begin{array}{c}0.1899^{* * *} \\
(0.0620)\end{array}$ & $\begin{array}{c}0.2343^{* *} \\
(0.0911)\end{array}$ & $\begin{array}{c}0.1277 \\
(0.0828)\end{array}$ \\
\hline UERate & $\begin{array}{c}0.0058 \\
(0.0063)\end{array}$ & $\begin{array}{c}0.0022 \\
(0.0108)\end{array}$ & $\begin{array}{c}0.0078 \\
(0.0084)\end{array}$ \\
\hline Unemployed ${ }^{*} U$ ERate & $\begin{array}{l}-0.0065 \\
(0.0166)\end{array}$ & $\begin{array}{l}-0.0059 \\
(0.0250)\end{array}$ & $\begin{array}{l}-0.0093 \\
(0.0198)\end{array}$ \\
\hline Unemployed ${ }^{*}$ WorkingSpouse & $\begin{array}{c}-0.1791^{* *} \\
(0.0759)\end{array}$ & $\begin{array}{l}-0.1321 \\
(0.1356)\end{array}$ & $\begin{array}{c}-0.1779 * * \\
(0.0854)\end{array}$ \\
\hline Number of Individuals & 4276 & 1764 & 2512 \\
\hline \multicolumn{4}{|c|}{$\begin{array}{l}\text { s.e. in parentheses } \\
\left({ }^{* *}\right) \text { denotes significance at the } 1 \% \text { level, }\left({ }^{*}\right) \text { at the } 5 \% \text { level, }\left({ }^{*}\right) \text { at the } 10 \% \text { level } \\
\text { Each specification is a OLS regression with Retire_Within_6_Months as the dependent vari- } \\
\text { able. We also include controls for age, as well as time and state fixed effects, an indicator } \\
\text { variable for the beginning of a new wave, and an indicator variable for the nth observation in } \\
\text { each panel. }\end{array}$} \\
\hline
\end{tabular}

Table 7: Social Security Withdrawl at 62nd Birthday

\begin{tabular}{|c|c|c|c|}
\hline & Full Sample & Below Median & Above Median \\
\hline Mean of Dependent Variable & 0.2642 & 0.2967 & 0.2427 \\
\hline WorkingSpouse & $\begin{array}{c}-0.0755^{* * *} \\
(0.0145)\end{array}$ & $\begin{array}{c}-0.0844^{* * *} \\
(0.0262)\end{array}$ & $\begin{array}{c}-0.0546^{* * *} \\
(0.0187)\end{array}$ \\
\hline Unemployed & $\begin{array}{c}0.3409^{* * *} \\
(0.0704)\end{array}$ & $\begin{array}{c}0.5334^{* * *} \\
(0.0823)\end{array}$ & $\begin{array}{c}0.0982 \\
(0.1014)\end{array}$ \\
\hline UERate & $\begin{array}{c}0.0130 \\
(0.0090)\end{array}$ & $\begin{array}{c}0.0102 \\
(0.0157)\end{array}$ & $\begin{array}{c}0.0090 \\
(0.0116)\end{array}$ \\
\hline Unemployed ${ }^{*} U$ ERate & $\begin{array}{l}-0.0044 \\
(0.0207)\end{array}$ & $\begin{array}{l}-0.0122 \\
(0.0274)\end{array}$ & $\begin{array}{l}-0.0067 \\
(0.0340)\end{array}$ \\
\hline Unemployed ${ }^{*}$ WorkingSpouse & $\begin{array}{l}-0.1675 \\
(0.1041)\end{array}$ & $\begin{array}{l}-0.2264 \\
(0.1499)\end{array}$ & $\begin{array}{c}0.0282 \\
(0.1418)\end{array}$ \\
\hline Number of Individuals & 4276 & 1764 & 2512 \\
\hline $\begin{array}{l}\text { s.e. in parentheses } \\
(* * *) \text { denotes significance at the } 1 \% \\
\text { Each specification is a OLS regressio } \\
\text { dent variable. We also include cont } \\
\text { indicator variable for the beginning } \\
\text { observation in each panel are also in }\end{array}$ & $\begin{array}{l}\text { evel, }(* *) \text { at the } \\
\text { with Social_Sec } \\
\text { ols for age, as } \\
\text { of a new wave, } \\
\text { luded. }\end{array}$ & $\begin{array}{l}5 \% \text { level, }(*) \text { at the } \\
\text { urity_Within_6_M } \\
\text { ell as time and sta } \\
\text { and an indicator v }\end{array}$ & $\begin{array}{l}10 \% \text { level } \\
\text { nths as the depen- } \\
\text { e fixed effects, an } \\
\text { riable for the nth }\end{array}$ \\
\hline
\end{tabular}


Table 8: Retirement Transitions by Unemployment Spell Length

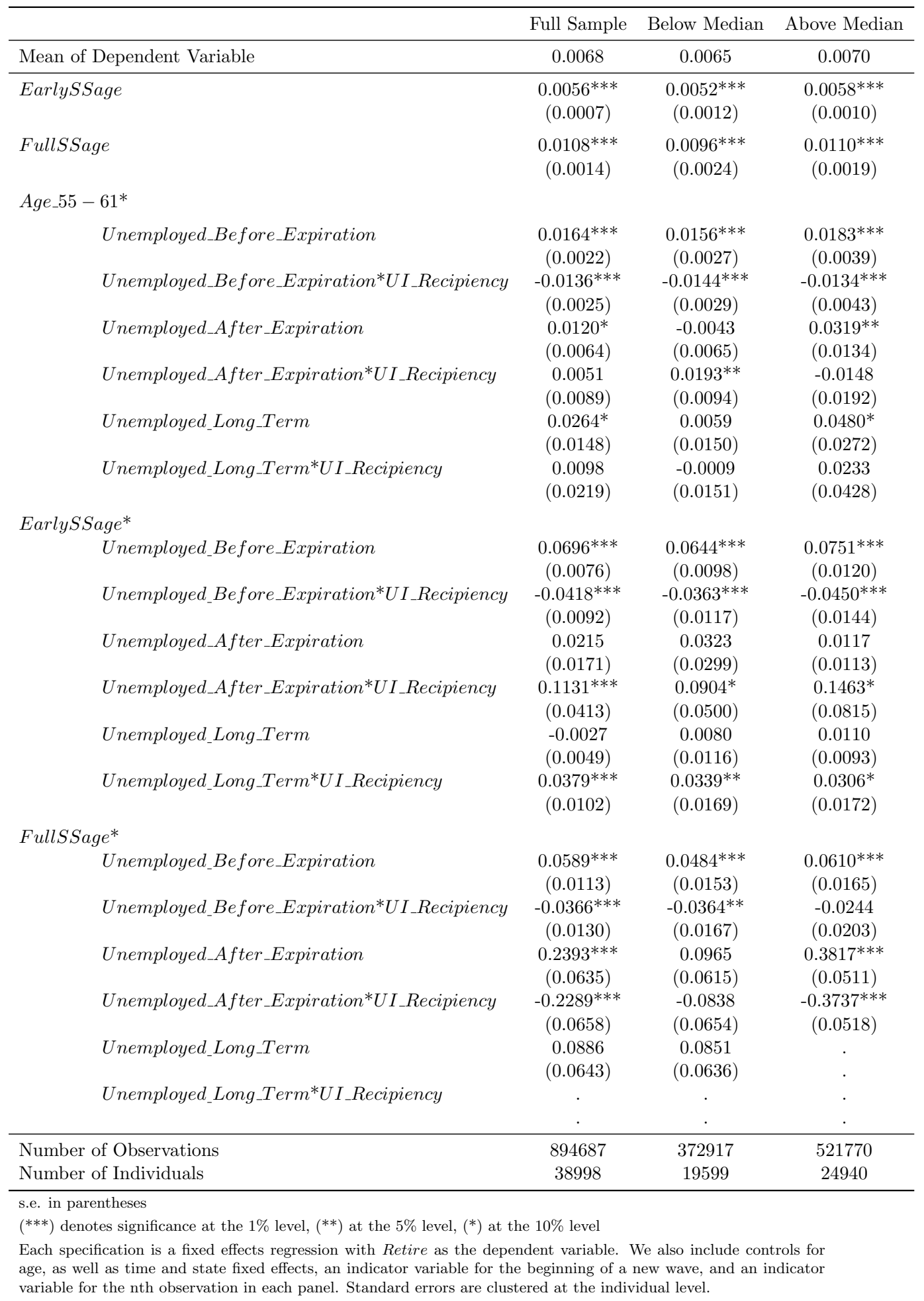


Table 9: Effect of UI Extension on Retirement Transitions

\begin{tabular}{|c|c|}
\hline & Full Sample \\
\hline Mean of Dependent Variable & 0.0069 \\
\hline EarlySSage & $\begin{array}{c}0.0068^{* * *} \\
(0.0009)\end{array}$ \\
\hline FullSSage & $\begin{array}{c}0.0135^{* * *} \\
(0.0018)\end{array}$ \\
\hline Unemployed_1 - 26_Weeks & $\begin{array}{c}0.0266^{* * *} \\
(0.0034)\end{array}$ \\
\hline Unemployed_1 - 26_Weeks*UI_Recipiency & $\begin{array}{c}-0.0194^{* * *} \\
(0.0040)\end{array}$ \\
\hline Unemployed_1 - 26_Weeks*99Extension & $\begin{array}{c}0.0011 \\
(0.0073)\end{array}$ \\
\hline Unemployed_1 - 26_Weeks*UI_Recipiency ${ }^{*} 99$ Extension & $\begin{array}{l}-0.0046 \\
(0.0080)\end{array}$ \\
\hline Unemployed_27 - 51_Weeks & $\begin{array}{c}0.0227^{* * *} \\
(0.0074)\end{array}$ \\
\hline Unemployed_27 - 51_Weeks*UI_Recipiency & $\begin{array}{c}0.0011 \\
(0.0103)\end{array}$ \\
\hline Unemployed_27 - 51_Weeks* ${ }^{*} 99$ Extension & $\begin{array}{c}0.0143 \\
(0.0124)\end{array}$ \\
\hline Unemployed_27 - 51_Weeks*UI_Recipiency*99Extension & $\begin{array}{c}-0.0274^{*} \\
(0.0151)\end{array}$ \\
\hline Unemployed_After_51_Weeks & $\begin{array}{c}0.0163^{*} \\
(0.0096)\end{array}$ \\
\hline Unemployed_After_51_Weeks*UI_Recipiency & $\begin{array}{c}0.0261 \\
(0.0202)\end{array}$ \\
\hline Unemployed_After_51_Weeks*99Extension & $\begin{array}{c}0.0265 \\
(0.0173)\end{array}$ \\
\hline Unemployed_After_51_Weeks*UI_Recipiency*99Extension & $\begin{array}{c}-0.0564^{* *} \\
(0.0253)\end{array}$ \\
\hline $\begin{array}{l}\text { Number of Observations } \\
\text { Number of Individuals }\end{array}$ & $\begin{array}{c}650023 \\
35992\end{array}$ \\
\hline
\end{tabular}

s.e. in parentheses

$\left({ }^{* *}\right)$ denotes significance at the $1 \%$ level, $\left({ }^{* *}\right)$ at the $5 \%$ level, $\left({ }^{*}\right)$ at the $10 \%$ level

The specification is a fixed effects regression with Retire as the dependent variable. We also include controls for age, as well as time and state fixed effects, an indicator variable for the beginning of a new wave, and an indicator variable for the nth observation in each panel. Standard errors are clustered at the individual level. 
Table 10: Retirement Transitions for 55-61 Year Olds by Total Household Net Worth

\begin{tabular}{|c|c|c|c|c|}
\hline & \multicolumn{2}{|c|}{ 3rd Quartile } & \multicolumn{2}{|c|}{ 4th Quartile } \\
\hline Mean of Dependent Variable & 0.0039 & 0.0039 & 0.0045 & 0.0045 \\
\hline StockReturn ${ }^{*} 100$ & $\begin{array}{c}-0.0008 \\
(0.0089)\end{array}$ & $\begin{array}{l}-0.0006 \\
(0.0089)\end{array}$ & $\begin{array}{c}0.0182 \\
(0.0120)\end{array}$ & $\begin{array}{c}0.0169 \\
(0.0120)\end{array}$ \\
\hline HomeValue *100 & $\begin{array}{c}0.0008 \\
(0.0031)\end{array}$ & $\begin{array}{c}0.0015 \\
(0.0032)\end{array}$ & $\begin{array}{l}-0.0018 \\
(0.0028)\end{array}$ & $\begin{array}{l}-0.0016 \\
(0.0030)\end{array}$ \\
\hline WorkingSpouse & & $\begin{array}{l}-0.0019 \\
(0.0013)\end{array}$ & & $\begin{array}{c}-0.0025^{* *} \\
(0.0010)\end{array}$ \\
\hline Unemployed & & $\begin{array}{c}0.0083^{* *} \\
(0.0033)\end{array}$ & & $\begin{array}{c}0.0198^{* * *} \\
(0.0060)\end{array}$ \\
\hline UERate & & $\begin{array}{c}0.0004 \\
(0.0005)\end{array}$ & & $\begin{array}{c}0.0000 \\
(0.0005)\end{array}$ \\
\hline Unemployed ${ }^{*}$ WorkingSpouse & & $\begin{array}{c}0.0045 \\
(0.0053)\end{array}$ & & $\begin{array}{l}-0.0057 \\
(0.0074)\end{array}$ \\
\hline Unemployed ${ }^{*}$ ERate & & $\begin{array}{l}-0.0005 \\
(0.0008)\end{array}$ & & $\begin{array}{l}-0.0004 \\
(0.0017)\end{array}$ \\
\hline Number of Observations & 166693 & 166693 & 181408 & 181408 \\
\hline Number of Individuals & 10732 & 10732 & 10308 & 10308 \\
\hline
\end{tabular}

s.e. in parentheses

$(* * *)$ denotes significance at the $1 \%$ level, $\left({ }^{* *}\right)$ at the $5 \%$ level, $(*)$ at the $10 \%$ level

Each specification is a fixed effects regression with Retire as the dependent variable. We also include controls for age, as well as time and state fixed effects, an indicator variable for the beginning of a new wave, and an indicator variable for the nth observation in each panel.

Standard errors are clustered at the individual level. 
Table 11: Retirement Transitions for 62-69 Year Olds by Total Household Net Worth

\begin{tabular}{lcccc}
\hline & \multicolumn{2}{c}{ 3rd Quartile } & \multicolumn{2}{c}{ 4th Quartile } \\
\hline Mean of Dependent Variable & 0.0140 & 0.0140 & 0.0118 & 0.0118 \\
\hline FullSSage & 0.0012 & 0.0011 & 0.0022 & 0.0025 \\
& $(0.0025)$ & $(0.0025)$ & $(0.0020)$ & $(0.0020)$ \\
StockReturn*100 & 0.0217 & 0.0217 & $0.0416^{*}$ & 0.0171 \\
& $(0.0317)$ & $(0.0316)$ & $(0.0225)$ & $(0.0257)$ \\
HomeValue*100 & 0.0074 & 0.0085 & -0.0011 & -0.0022 \\
& $(0.0080)$ & $(0.0084)$ & $(0.0069)$ & $(0.0073)$ \\
WorkingSpouse & & $-0.0067^{* *}$ & & $-0.0045^{* *}$ \\
& & $(0.0031)$ & & $0.0020)$ \\
Unemployed & & $0.0621^{* * *}$ & & $0.0519^{* * *}$ \\
& & $(0.0131)$ & & $(0.0132)$ \\
UERate & & -0.0004 & & -0.0010 \\
& & $(0.0014)$ & & $(0.0013)$ \\
Unemployed ${ }^{*}$ WorkingSpouse & & $-0.0454^{* *}$ & & -0.0017 \\
& & $(0.0186)$ & & $(0.0216)$ \\
Unemployed ${ }^{*}$ ERate & & $0.0064^{*}$ & & 0.0008 \\
& & $(0.0038)$ & & $(0.0041)$ \\
\hline Number of Observations & 79542 & 79542 & 94127 & 94127 \\
Number of Individuals & 5580 & 5580 & 5717 & 5717 \\
\hline
\end{tabular}

s.e. in parentheses

$(* * *)$ denotes significance at the $1 \%$ level, $\left({ }^{* *}\right)$ at the $5 \%$ level, $\left({ }^{*}\right)$ at the $10 \%$ level

Each specification is a fixed effects regression with Retire as the dependent variable. We also include controls for age, as well as time and state fixed effects, an indicator variable for the beginning of a new wave, and an indicator variable for the nth observation in each panel. Standard errors are clustered at the individual level. 